\title{
管フランジ用らず巻形ガスケット日本工業規格 (案)についで
}

岩浪繁蔵

\section{1. 規格（案）作成のいきさつ}

うず巻形ガスケットについてはイギリス規格（British Standard, B.S. 3381；1961),アメリカ石油学会 規格（A.P.I. Spec.，1958）等があるが，わが国では これに関する規格はなく，製造者が各自社内規格によ っている現状にある，日本機械学会は通産省工業技術 院工業標準部の委託を受け，工業標準委員会に JIS 管 フランジ用うず巻形ガスケット分科会**を設け昭和37 年 7 月より昭和 38 年 3 月まで，分科会 6 回，小委員 会 4 回，合計 10 回の審議を経てこの規格案を作成し た。なお期間が短かったため，期間中に決定できなか った点（たとえぼ性能についての具体的な事項，解 説等）については，引続き小委員会の委員の間で検討 中にて，本規格に関する JIS 本委員会には成案が出せ る予定である。

2. 問題となった点

本分科会において問題となったおもなものは（1) 適 用範围，(2) 種類および構造，(3) 材料，(4) 形状抢よび 寸法, (5) 性能, (6) 寸法の測定方法等であって, 検討 すべき問題が多く，共同試験に基いて客議をする問題 もあり，与えられた期間内に十分論議をつくせなかっ たものも若干ある. 次に問題となった点について略述 する.

$2 \cdot 1$ 適用範囲 JIS 管フランジには $2 \mathrm{~kg} / \mathrm{cm}^{2}$, $5 \mathrm{~kg} / \mathrm{cm}^{2}, 10 \mathrm{~kg} / \mathrm{cm}^{2}, 16 \mathrm{~kg} / \mathrm{cm}^{2}, 20 \mathrm{~kg} / \mathrm{cm}^{2}, 30 \mathrm{~kg} /$ $\mathrm{cm}^{2}, 40 \mathrm{~kg} / \mathrm{cm}^{2}$ および $63 \mathrm{~kg} / \mathrm{cm}^{2}$ について規定して いるが，このうち $2 \mathrm{~kg} / \mathrm{cm}^{2}$ および $5 \mathrm{~kg} / \mathrm{cm}^{2}$ の場合 については，規定されたボルトの許容虑力值以内で締 付忊た場合，漏れ止め作用のため十分な接面圧力を与 えるようなうず巻形ガスケットを設定することは困難

* 原稿受付 昭和 38 年 3 月 11 日.

** 主查 岩浪繁蔵 (東京都立大学), 幹事 石井毅一 (日本バルカ 一工業会社), 委員 家崎三男 (石川島播磨重工業会社), 小野辰 成 (東京電力会社), 清水敏郎 (横山工業会社), 田中克巳 (日本 ピラ一工業会社), 東 秀彦 (工業技術院), 福塚吉一 (新三菱重 工業会社), 町田甲子郎 (新潟鉄工所)，三島宣夫 (東然石油化学 会社), 山岡孝造 (日本揮発油会社), 山本久吉 (日本アスペスト 会社)，渡利美雄 (東京芝浦電気会社)。
であるから、これらは除外した。

$2 \cdot 2$ 種類および構造 うず巻形ガスケットは，テ 一プ状の金属製波形薄板（フープ）と石綿紙とを重ね てうず巻形に巻いて作ったガスケット本体のみからな る基本形のものと，本体の内側に金属製リングを取り つけた内輪付，本体の外側に金属製リングを取りつけ た外輪付，その両者を取りつ汁た内外輪付とが用いら れている.これらのうち内輪の必要性については多少 の異論もあったが，使用の実情を考慮して採用するこ とにした。

ガスケット本体の金属製波形薄板の形状には，現在 図示のような 2 種類が国内において製造使用され，こ れらの特性值について比較試験を行なった結果からも 一方に統一すべき根拠は見出されないため，現状にお いては一応両種の形式を例として諗めることにした。 ガス用，水蒸気，液体用等の区別も論議されたが，両 者を含めたものについて規定した。

$\mathbf{2 \cdot 3}$ 材 料 ガスケット本体の金属製波形薄板材 料については，軟鋼，SUS 27 および特に高温 $\left(550^{\circ} \mathrm{C}\right.$ まで）の使用温度には SUS 32 が使用される場合が多 いが，規格では標準品を目標として原則として SUS 27 とした。石綿紙は現在の使用実状に基いて決定し た.内輪の材料は SUS 22 が多いのでこれを原則とし た.

2.4 形状および寸法 （1）ガスケット本体の形状 と厚さ

ガスケット本体の金属製波形薄板の形状にはV形と W形とが別々の製造者によって製造され，これらが広 く国内において使用きれ，その優劣を評価し難い現状 にあり，本規格案には両者を例として認めている．カ加 スケット本体の厚さ（金属フープの縁で測定）はこの 形状に関連して V 形は $4.5 \mathrm{~mm}, W$ 形は $4.8 \mathrm{~mm}$ で ありこれらを同一寸法に統一するよう要望され，本 委員会においてもその実現を希望した。本期間中にお いて同一称呼寸法の試料についての試験等も行なった が，一定寸法に統一した場合ガスケット特性に及はす 影響について確実な資料が得られないため，現状に おいては $4.5,4.8 \mathrm{~mm} の 2$ 本立とし, 今後試験研究 
の期間を置いて将来一定值へ統一するよう努力するこ とにした。

（2）ガスケット標準寸法の決定

ガスケットの寸法は JIS 管フランジに規定されたガ スケット座の寸法をもとにして，フランジおよびガス タットの公差，ゆるみ等を考虑して機能上さしつかえ ないように寸法を決めなければならないまただスケ ット幅は JIS 管フランジ規格に規定されたボルトの許 容応力内の締付力で漏れ止めに必要なガスケットの 接面圧力が得られるような寸法で，かつガスケットの 構造上機能上必要な幅以上のものであることが必要で ある. 委員会ではボルトの締付汒力を $17.5 \mathrm{~kg} / \mathrm{mm}^{2}$ （降伏㲿力の約 $70 \%$ にとる）とおいて，ガスケットの 締付面圧力 $\sigma_{g 0}$ が注涩第 1 表の值以上になるようにガ スケット幅 $W$ をめた。

なおガスケット本体の幅 $W$ は $6 \mathrm{~mm}$ 未満の場合は 漏れ試験の結果のぼらつきが大きくなるおそれもある ので，やむを得ない二，三の場合を除いて幅を $6 \mathrm{~mm}$ 以上にとった。

みぞ形フランジ用のガスケットはみぞの中に取りつ

第 1 表 計算に仮定した最低締付面圧力 $\sigma_{g 0}$

\begin{tabular}{c|c|c|c|c|c}
\hline 乎 $\begin{array}{c}\text { 无 } \\
\mathrm{kg} / \mathrm{cm}^{2}\end{array}$ & 10 & 16,20 & 30 & 40 & 63 \\
\hline$\sigma_{g o}$ & 300 & 400 & 500 & 600 & $800 \sim 1000$ \\
\hline
\end{tabular}

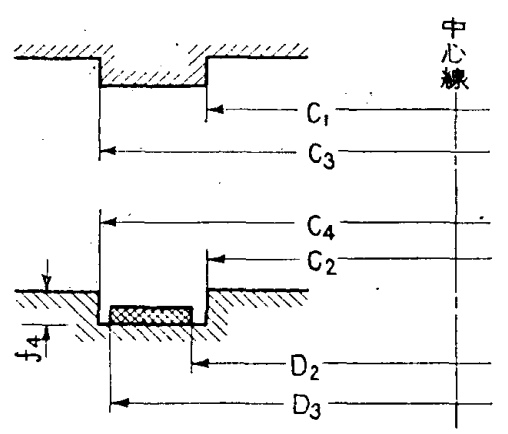

(単位 $\mathrm{mm}$ )

$C_{1}=C_{2}+1, C_{3}=C_{4}-1$

$D_{3}=C_{3}-\Delta x, \quad D_{2}=C_{1}+\Delta x$ $\Delta x$ はガスケットの許容差

第 1 図 みぞ形フランジ用ガスケットの内外径

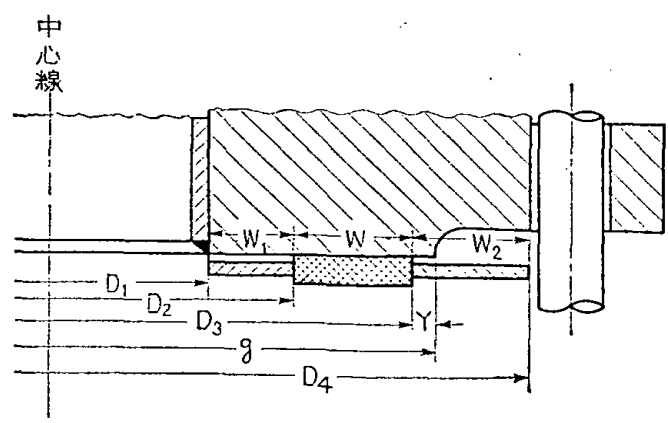

$Y:$ 余 95

第 2 図 大平面座におけるガスケット寸法の関係
けるガスケットの内外径は第 1 図に示すように笑出部 の外にはずれないように寸法をきめた。なおみ兮の深 さは $5 \mathrm{~mm}$ 以上にとるよう備考に付記した。

大平面座フランジに用いるガスケットについては， ガスケット本体の寸法は内輪付の場合にも外輪付の場 合にも共通のものとし，第2 四に示すようにガスケッ 卜本体の外堡 $D_{3}$ は座の㨁径 $g$ 上り $Y$ のゆるみを取っ て小さくきめた（ $Y$ の值はこれに関係する公差やゆる みの総和から求めた). 内径 $D_{2}$ は締付面圧力を考慮し て導かれるガスケット幅についての制限を満しかつ内 輪幅 $W_{1}$ は少なくとも $3 \mathrm{~mm}$ 以上とり得るように決定 した。内輪の内径はフランジ座の内径（管の外径）に 一致させ, 外輪の外径 $D_{4}$ は $D_{4}=$ (ボルト中心径)一 (ボルト径)一(外签寸法許容差)に基いてきめている。

内輪掞よび外輪の厚さはこれを作り出す金属板の規 格值をそのままをり入れ，輸の強度上から厚さをSUS 22 (JIS G 4305) については同規格による厚さ $2 \mathrm{~mm}$ 以上のものを，軟鋼板（JIS G 3101 または JIS G 3310)については同規格による厚さ $2.6 \mathrm{~mm}$ 以上のも のとした（最大厚さはガスケット本体の厚さから自然 に制限されている).

2.5 性 能 ガスケットの性能検査については製 造者側加らも要望がありその試験装置，方法等もあわ せ討議し，同一称呼寸法の試料について圧縮ひずみお よび復元試験と漏れ試験を実施し，これらの餈料に基 いて性能検查の規定を確立すべく努力している途上 にある。

$2 \cdot 6$ ガスケット本体の寸法測定方法 ガスケット 本体の内外径の測定は金属製フープの端が溶接によっ て止められていること，大形のものは輸送中に変形す ることがあるため，その測定方法拐よび判定について 種々意見があったが，製造者側における測定法および 公差は規格案に示すようにフープの巻き初め䇢所の直 径と，これと直交する㨁径の平均值について考えその 公差を与え，輸送先での受入検査については実情に即 した方法を解説中に述べることとした。

\section{3. 付 記}

なおうず巻形ガスケットの性能を中心にきめた本規 格案の側から現行 JIS 管フランジ規格に対し直ちに改 善を希望する点として，(1) みぞ形フランジみその深 さ $f_{4}$ を $5 \mathrm{~mm}$ 以上にとること, (2) みそ幅 $\left(C_{4}-C_{2}\right) / 2$ を $8 \mathrm{~mm}$ 以上にすること, (3) 呼び径 $90 \mathrm{~mm}$ 以上の $63 \mathrm{~kg} / \mathrm{cm}^{2}$ フランジの座の直径 $g$ を本規格案に示すガ スケット本体の外径 $D_{3}$ より大きくとること，の 3 点 を指示申請した。 